\title{
Nickel(II) Complex with a Flexidentate Ligand Derived from Acetohydrazide: Synthesis, Structural Characterization and Hirshfeld Surface Analysis
}

\author{
Rasoul Vafazadeh, ${ }^{1,}{ }^{*}$ Zahra Mansouri ${ }^{1}$ and Anthony C. Willis ${ }^{2}$ \\ ${ }^{1}$ Department of Chemistry, Yazd University, Yazd, Iran. \\ ${ }^{2}$ Research School of Chemistry, Australian National University, Canberra, ACT 2601, Australia. \\ *Corresponding author: E-mail: e-mail address: rvafazadeh@yazd.ac.ir \\ Tel: +98351 8214778; Fax: +983517250110
}

Received: 09-02-2019

\begin{abstract}
The mononuclear $\mathrm{Ni}(\mathrm{II})$ complex $\left[\mathrm{Ni}\left(\mathrm{L}^{\mathrm{P}}\right)_{2}\left(\mathrm{CH}_{3} \mathrm{OH}\right)_{2}\right] \mathrm{Cl}_{2}$ has been synthesized by reacting 1-(5-hydroxy-3-methyl-5phenyl-4,5-dihydro-1H-pyrazol-1-yl)ethan-1-one ligand (HL) with $\mathrm{NiCl}_{2} \cdot 6 \mathrm{H}_{2} \mathrm{O}$ in methanol solution. In the reaction, the tridentate ligand, HL, was converted in situ into 4-hydroxy-4-phenylbut-3-en-2-ylidene)acetohydrazid ligand, (pyrazole, $\mathrm{L}^{\mathrm{p}}$ ). The pyrazole ligand acts as bidentate neutral ligand and the hydroxyl group is left uncoordinated. The structure of the $\mathrm{Ni}(\mathrm{II})$ complex has been established by $\mathrm{X}$-ray crystallography. The $\mathrm{Ni}(\mathrm{II})$ is six-coordinate and has a distorted octahedral geometry. It is bonded by two nitrogen and by two oxygen atoms of the two pyrazole ligands and two oxygen atoms of methanol molecules. The Hirshfeld surface analysis and the $2 \mathrm{D}$ the fingerprint plot are used to analyses all of the intermolecular contacts in the crystal structures. The main intermolecular contacts are $\mathrm{H} / \mathrm{H}$ and $\mathrm{Cl} / \mathrm{H}$ interactions.
\end{abstract}

Keyword: Flexidentate ligand; pyrazole ligand; Hirshfeld surface; fingerprint plot; hydroxyl group

\section{Introduction}

The complexation of transition metal ions with multidentate Schiff base ligands has been studied extensively as their structures can be divers and they can have versatile properties. ${ }^{1-3}$ The hydrazone ligands which are formed by condensation reactions between hydrazide derivatives and relevant aldehyde or ketones, are a signification class of such multidentate ligands. Metal complexes with these ligands can have a wide range of structures with significant variations in geometry. ${ }^{3-7}$ Also, the cyclization reaction of hydrazide precursors may take place and lead to the formation of pyrazole ligands. ${ }^{8-10}$ The pyrazole compounds themselves are hydrolytically and thermally stable and can act as a mono- or bidentate ligands. The pyrazoles and their complexes can have interesting structural features, properties and biologically actives. ${ }^{11-14}$

In our previous work, we reported the synthesis of CuLX complexes where HL is 1-(5-hydroxy-3-methyl-5phenyl-4,5-dihydro-1H-pyrazol-1-yl)ethan-1-one ligand
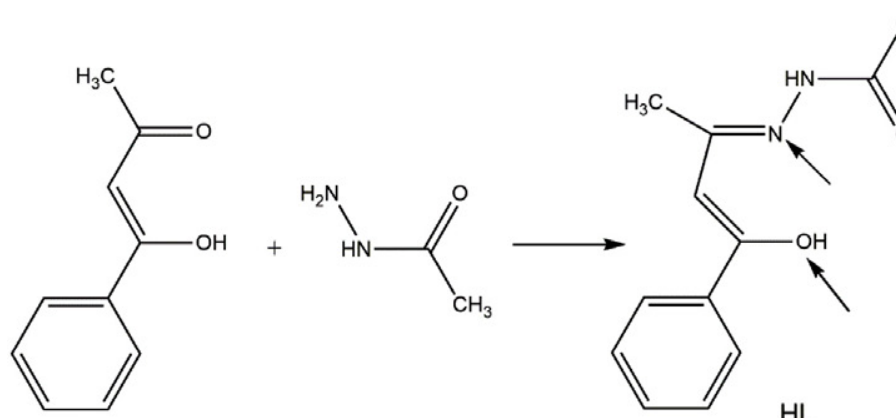

HL

Scheme 1. Preparation of HL and $\mathrm{L}^{\mathrm{p}}$ ligands with potential ligating sites 
(Scheme 1). ${ }^{15}$ In these complexes, the hydrazone ligand was in the keto form and acted as a tridentate monoanionic. In order to investigate the effect of the metal on the coordination behavior of the hydrazone ligand, we report here the reaction of $\mathrm{Ni}(\mathrm{II})$ salts with $\mathrm{HL}$. In situ, the ligand is converted into the 4-hydroxy-4-phenylbut-3-en-2-ylidene)acetohydrazide ligand, (pyrazole, $\mathrm{L}^{\mathrm{p}}$ ) by the self-cyclization reaction of $\mathrm{HL}$ in the presence $\mathrm{NiCl}_{2}$. The pyrazole coordinates to $\mathrm{Ni}(\mathrm{II})$ and act as bidentate neutral ligand and the hydroxyl group is left uncoordinated (Scheme 1).

A search of the literature revealed that the pyrazole had been reported previously by Wang et al. and Alberola et al. and crystal structure has also been determined. ${ }^{16,17}$ Pyrazole has been prepared by the reaction of 1-phenylbutane-1,3-dione and acetohydrazide in the presence of a catalytic amount of acid under solventless conditions ${ }^{16}$ or in solvent. ${ }^{17}$

\section{Experimental Section}

\section{1. Starting Materials}

All chemicals were of analytical reagent grade and were used without further purification.

Caution! Transition-metal complex perchlorate salts are known to be hazardous and must be treated with care, especially in the presence of organic solvents.

\section{2. Physical Measurements}

Infrared spectra were taken with an Equinox 55 Bruker FT-IR spectrometer using $\mathrm{KBr}$ pellets in the 400 $4000 \mathrm{~cm}^{-1}$ range. Absorption spectra were determined using methanol and dimethylformamide (DMF) solutions in a GBC UV-Visible Cintra 101 spectrophotometer with a 1 $\mathrm{cm}$ quartz cell, in the range $200-800 \mathrm{~nm}$. Elemental analyses $(\mathrm{C}, \mathrm{H}, \mathrm{N})$ were performed by using a CHNS-O $2400 \mathrm{II}$ PERKIN-ELMER elemental analyzer.

\section{3. X-ray Crystallography and Hirshfeld Surfaces Analyses}

Single-crystal X-ray diffraction data were collected at $150 \mathrm{~K}$ on an Agilent SuperNova diffractometer using $\mathrm{Cu} \mathrm{Ka}$ $(\lambda=1.54180 \AA)$ radiation. Data were extracted using the CrysAlis PRO package. ${ }^{17}$ The structures were solved by direct methods with the use of SIR92. ${ }^{19}$ The structures were refined on $F^{2}$ by full matrix last-squares techniques using the CRYSTALS program package. ${ }^{20}$ The $\mathrm{H}$ atoms were initially refined with soft restraints on the bond lengths and angles to regularize their geometry $(\mathrm{C}-\mathrm{H}$ in the range $0.93-$ $0.98 \AA, \mathrm{O}-\mathrm{H}=0.83 \AA$ ) and with $U_{\text {iso }}(\mathrm{H})$ in the range 1.2-1.5 times $U_{\text {eq }}$ of the parent atom. After this, the positions of the $\mathrm{H}$ atoms bonded to $\mathrm{O}$ and $\mathrm{N}$ were refined without constraints whereas those bonded to $\mathrm{C}$ ride on the atoms to which they are bonded. Crystallographic data and refinement details for the complex is given in Table 1 .
Table 1. Crystallographic data of the complex 1

\begin{tabular}{cc}
\hline Compound & {$\left[\mathrm{Ni}\left(\mathbf{L}^{\mathbf{p}}\right)_{2}\left(\mathrm{CH}_{3} \mathbf{O H}\right)_{2}\right] \mathbf{C l}_{2}$} \\
\hline Chemical formula & $\mathrm{C}_{26} \mathrm{H}_{36} \mathrm{Cl}_{2} \mathrm{~N}_{4} \mathrm{NiO}_{6}$ \\
Formula weight & 630.21 \\
Temperature $(\mathrm{K})$ & 150 \\
Space group & Orthorhombic, $\mathrm{Pbca}$, \\
$a(\AA)$ & $7.3033(1)$ \\
$b(\AA)$ & $19.2677(1)$ \\
$c(\AA)$ & $20.4218(1)$ \\
$Z$ & 4 \\
$F(000)$ & 1320 \\
$\left.D_{\text {Calc }}(\mathrm{g} \mathrm{cm})^{-3}\right)$ & 1.457 \\
Crystal size $(\mathrm{mm})$ & $0.22 \times 0.12 \times 0.11$ \\
$\left.\mu(\mathrm{mm})^{-1}\right)$ & 3.08 \\
$\mathrm{GOF}$ on $F^{2}$ & 1.020 \\
$R\left[F^{2}>2 \sigma\left(F^{2}\right)\right]$ & 0.029 \\
$w R\left(F^{2}\right)($ all data $)$ & $0.072^{*}$ \\
\hline$* w=1 /\left[\sigma^{2}\left(F^{2}\right)+(0.04 P)^{2}+21 P\right]$ & where $P=\left(\max \left(F^{2} 0\right)+2 F_{c}^{2}\right) / 3$
\end{tabular}

Hirshfeld surfaces analysis and the associated two-dimensional fingerprint plots for the complexes were calculated with CrystalExplorer 3.1 program. ${ }^{21}$ The $d_{\text {norm }}$ surface and $2 \mathrm{D}$ fingerprint were used to analyses intermolecular interaction in the crystal packing.

\section{4. Syntheses of HL Ligand}

The Schiff base ligand, HL, was prepared as previously reported elsewhere by us. ${ }^{15}$ Briefly, the ligand was obtained by condensation of equimolar amounts of benzoylacetone $(20 \mathrm{mmol}, 3.24 \mathrm{~g})$ and acetohydrazide $(20 \mathrm{mmol}, 1.48 \mathrm{~g})$ in methanol $(30 \mathrm{~mL})$. The mixture was refluxed for $2 \mathrm{~h}$ during which a light-yellow precipitate was formed. The reaction mixture was then cooled to room temperature and the solid compound formed was filtered. The compound was recrystallized from warm acetone. Yield $67 \%$. IR $\left(\mathrm{KBr}, \mathrm{cm}^{-1}\right)$ : $v \mathrm{C}=\mathrm{N}=1610, v \mathrm{C}=\mathrm{O}=1650$. Electronic spectra in acetone: $\lambda_{\max }(\mathrm{nm}),(\log \varepsilon): 333$ (2.66), 232 (4.29).

\subsection{Synthesis of $\mathrm{Ni}(\mathrm{II})$ Complex, $\left[\mathrm{Ni}\left(\mathrm{L}^{\mathrm{P}}\right)_{2}\left(\mathrm{CH}_{3} \mathrm{OH}\right)_{2}\right] \mathrm{Cl}_{2}, 1$.}

This complex was obtained as an unexpected product from following reaction: $\mathrm{NiCl}_{2} \cdot 6 \mathrm{H}_{2} \mathrm{O}(2 \mathrm{mmol}, 0.475 \mathrm{~g})$ was added to a stirred solution of the ligand HL $(2 \mathrm{mmol}$, $0.434 \mathrm{~g})$ in methanol $(30 \mathrm{~mL})$ and the resulting solution was stirred at room temperature for $2 \mathrm{~h}$. The solution's color turned green. After two days, blue block-shaped crystals of the $\left[\mathrm{Ni}\left(\mathrm{L}^{\mathrm{p}}\right)_{2}\left(\mathrm{CH}_{3} \mathrm{OH}\right)_{2}\right] \mathrm{Cl}_{2}$ complex suitable for X-ray analysis appeared at the bottom of the vessel. They were filtered off and dried in air. Yield: $61 \%$ based on HL. Anal. Calc. for $\mathrm{C}_{26} \mathrm{H}_{36} \mathrm{C}_{12} \mathrm{~N}_{2} \mathrm{NiO}_{6}$ : C, 49.55; $\mathrm{H}, 5.76 ; \mathrm{N}, 8.89 \%$. Found: C, 49.47; H, 5.62; N, 8.84\%. IR $\left(\mathrm{KBr}, v_{\max } / \mathrm{cm}^{-1}\right)$ : $v \mathrm{C}=\mathrm{N}=1587, v \mathrm{C}=\mathrm{O}=1605$. UV-Vis, $\lambda_{\max }($ methanol $) / \mathrm{nm}$ : $784(\log \varepsilon, 0.93), 371$ (3.50) and 207 (4.54). 
By comparison, the corresponding reactions of $\mathrm{NiX}_{2}$ $\left(\mathrm{X}=\mathrm{NO}_{3}{ }^{-}\right.$and $\mathrm{ClO}_{4}^{-}$) with $\mathrm{HL}$ were undertaken under the same conditions, but it was found that new Ni(II) complexes were not formed and the sole product isolated from the preparative mixtures were the initial salt, i.e. $\mathrm{NiX}_{2}$.

\section{Results and Discussion}

\section{1. Synthesis and Characterization of the Complexes}

Complex 1 was obtained by the reactions of $\mathrm{NiCl}_{2}$. $6 \mathrm{H}_{2} \mathrm{O}$ with an equimolar amount of the ligand $\mathrm{HL}$ in methanol solution at room temperature. The reaction of $\mathrm{NiCl}_{2}$ with HL ligand did not lead to formation of the NiL$\mathrm{Cl}$ complex. The ligand instead was converted in situ into the pyrazole ligand, $\mathrm{L}^{\mathrm{p}}$ under the reaction conditions. $\mathrm{L}^{\mathrm{P}}$ coordinates to the $\mathrm{Ni}(\mathrm{II})$ center, acting as a neutral bidentate ligand and leading to an unexpected product, $\left(\mathrm{Ni}\left(\mathrm{L}^{\mathrm{p}}\right)_{2}\left(\mathrm{CH}_{3} \mathrm{OH}\right)_{2}\right] \mathrm{Cl}_{2}$. In contrast, the reaction of copper(II) salts with this ligand did not lead to a cyclization reaction, and the copper complexes which were formed have the ligand acting as a monoanionic tridentate species, i.e. $[\mathrm{CuLX}]{ }^{15}$ The cyclization reactions in the $\mathrm{Ni}(\mathrm{II})$ case may occur due to formation of an unstable $\mathrm{Ni}$ (II) complex with $\mathrm{HL}$ or $\mathrm{Ni}(\mathrm{II})$ may have catalyzed the cyclization reaction.

The IR spectrum of the free HL ligand shows bands at 1610 and $1650 \mathrm{~cm}^{-1}$, which is assigned as $\nu \mathrm{C}=\mathrm{N}$ and $\nu \mathrm{C}=\mathrm{O}$, respectively. ${ }^{3,22,23}$ In the IR spectra of complex, these bands were shifted toward lower energy in comparison with the free ligand, which indicates coordination of the imine nitrogen atom and the carbonyl group to the nickel ion. ${ }^{23-25}$ The fairly broad band of medium intensity appearing at around $3400 \mathrm{~cm}^{-1}$ corresponds to the intramolecular hydrogen bonding in the free ligand, this band in the complex is observed in around the $3050 \mathrm{~cm}^{-1}$ re- gion, which indicates that the hydroxyl group remains as an uncoordinated $\mathrm{OH}$ group. ${ }^{26-28}$

\section{2. Description of Crystal Structure of the Complex 1}

The structural fragment of the complex $\mathbf{1}$ is shown in Fig. 1. The complex crystallizes in orthorhombic space group $\mathrm{Pbca}$ and there are four molecules in the unit cell ( $\mathrm{Z}$ $=4)$. As shown by Fig. 1, the crystallographic asymmetric unit is one-half of the structural fragment and consists of a $\mathrm{Ni}(\mathrm{II})$ atom, one $\mathrm{L}^{\mathrm{p}}$ ligand, a coordinated methanol and a chloride counter anion. The remainder of the cation is generated by a crystallographic inversion symmetry operation centered on the metal.

The $\mathrm{Ni}(\mathrm{II})$ is sixcoordinate (N2O4 donor atoms) and has a distorted octahedral geometry. The equatorial plane is formed by two nitrogen and two oxygen atoms from two $\mathrm{L}^{\mathrm{p}}$ ligands coordinates to the metal center. The ligands with $\mathrm{Ni}(\mathrm{II})$ atom formed five-membered chelate rings. The two axial positions are occupied by oxygen atoms of the two methanol molecules.

The Ni-N bond length in the complex is 2.067(1) $\AA$. The Ni-O bond length at the axial position $(2.061(1) \AA)$ is slightly longer than the corresponding bond in the equatorial plane $(2.037(1) \AA)$. The $\mathrm{Ni}-\mathrm{O}$ and $\mathrm{Ni}-\mathrm{N}$ bond lengths of the complex are in good agreement with $\mathrm{Ni}(\mathrm{II})$ complexes previously reported. ${ }^{29-31}$ The chelating $\mathrm{N}-\mathrm{Ni}-\mathrm{O}$ angle is $79.37(4)^{\circ}$, whereas the non-chelating $\mathrm{N}-\mathrm{Ni}-\mathrm{O}$ angles is $100.63(4)^{\circ}$. The $\mathrm{O} 3-\mathrm{Ni1}-\mathrm{O} 1$ and $\mathrm{O} 3-\mathrm{Ni1}-\mathrm{N} 1$ angles are $88.20(4)^{\circ}$ and $89.47(5)^{\circ}$, respectively. The C4-O1 bond distance of 1.232(3) $\AA$ agrees well with the value of $\mathrm{C}=\mathrm{O}$ bond as already observed in similar compounds. ${ }^{32}$ This bond length is similar to the carbonyl group bond length in uncoordinated pyrazole (1.241 and $1.229 \AA) .{ }^{16,17}$ The C3-O2 bond length of the alcohol group (1.391(2) A) is longer than the bond length of the carbonyl group ( $\mathrm{C} 4-$ $\mathrm{O} 1$ ) and similar to $\mathrm{C}-\mathrm{O}$ (hydroxyl) bond length in uncoor-

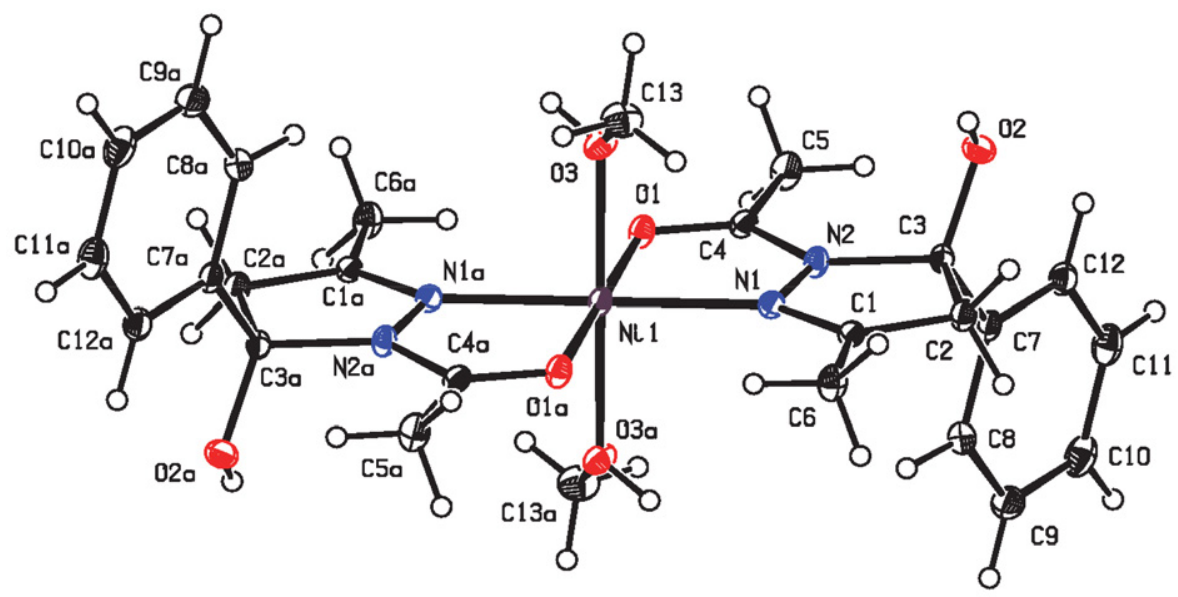

Fig. 1. The molecular structure of complex 1 with labelling of selected atoms, ellipsoids show $30 \%$ probability levels (symmetry code: (a) $-x+1,-y$ $+1,-z+1)$. 
dinated pyrazole (1.413 and $1.395 \AA$ A $){ }^{16,17}$ Selected bond lengths and angles, are summarized in Table 2.

The sum of the internal angles of the pyrazole ring in complex $1\left[\mathrm{~N} 1-\mathrm{N} 2-\mathrm{C} 1-\mathrm{C} 2-\mathrm{C} 3=539.78^{\circ}\right]$ shows the planarity of this ring since it is very close to the ideal value of $540^{\circ}$. The value is also close to the internal angles of the uncoordinated pyrazole ring uncoordinated (549.78 and $\left.539.61^{\circ}\right)$. The planarity is also illustrated by the small deviations of the atoms of the pyrazole ring from the corresponding mean plane (0.008-0.028 $\AA$ ). In the uncoordinated pyrazole which was synthesized by Wang et al. and Alberola et al., the deviate from the plane are in the 0.006$0.028 \AA$ and $0.009-0.032 \AA$ rang, respectively. ${ }^{16,17}$

Table 2. Selected bond lengths $(\AA)$ and angles $\left(^{\circ}\right)$ in the Ni(II) complex

\begin{tabular}{lllr}
\hline Ni1-O1 & $2.0372(10)$ & O1-Ni1-N1 & $79.37(4)$ \\
Ni1-O3 & $2.0606(11)$ & O1-Ni1-O3 & $88.20(4)$ \\
Ni1-N1 & $2.0674(12)$ & O1-Ni1-N1 ${ }^{a}$ & $100.63(4)$ \\
C4-O1 & $1.2476(18)$ & N1-Ni1-O3 & $89.47(5)$ \\
C3-O2 & $1.3914(18)$ & C3-N2-N1 & $112.21(10)$ \\
C4-N2 & $1.3434(18)$ & N2-N1-C1 & $109.12(11)$ \\
C3-N2 & $1.5160(17)$ & O1-C4-N2 & $120.44(13)$ \\
C1-N1 & $1.2814(18)$ & C3-O2-H2 & $107.90(17)$ \\
\hline
\end{tabular}

Symmetry code: (a) $-x+1,-y+1,-z+1$.

The mean planes of the pyrazole and aromatic rings in complex $\mathbf{1}$ are almost perpendicular. The dihedral angle is ca. $87.66^{\circ}$ which is similar to the values found in uncoordinated pyrazole previously reported (85.73 and $\left.85.79^{\circ}\right) .16,17$

The chloride counter anions are involved in intermolecular and intramolecular hydrogen bonding interaction with the $\mathrm{OH}$ groups of the uncoordinated hydroxyl of the ligand and coordinated methanol molecule, which build a
1D chain structure running through the $a$ axis (Fig. 2). The $\mathrm{Ni} \cdots \mathrm{Ni}$ distance is $7.303 \AA$, which is much longer than the van der Waals radii sum for nickel (3.26 $\AA$ ), showing that there is no interaction between the nickel atoms. The distance between $\mathrm{Cl}$ and the center of aromatic ring from adjacent complex and centers of aromatic rings are 6.489 and $7.303 \AA$, showing that there are no $\mathrm{Cl} \cdots \pi$ and $\pi \cdots \pi$ interactions in the packing for complex 1.

Full details of the hydrogen bonding are given in Table 3 .

\section{3. Hirshfeld Surface Analyses}

The Hirshfeld surface analyses and the fingerprint plots provide some useful quantitative information about the strength and role of the intermolecular contacts, and to estimate their importance in the in the crystal packing stability. ${ }^{1,26,33,34}$ In Fig. 3, the 3D Hirshfeld surface mapped are shown over a $d_{\text {norm }}$ (normalized contact distance) range of $-0.705-1.148 \AA$. The value of the $d_{\text {norm }}$ can be

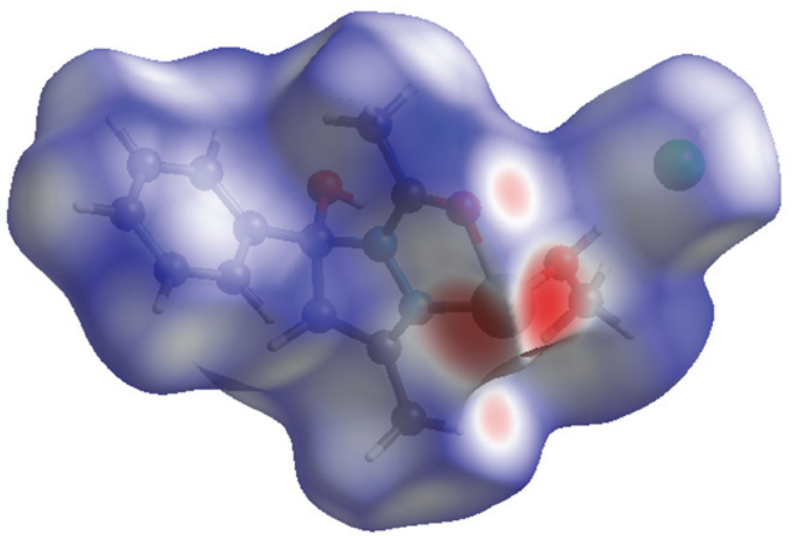

Fig. 3. Hirshfeld surface mapped with $d_{\text {norm }}$ for complex $\mathbf{1}$.

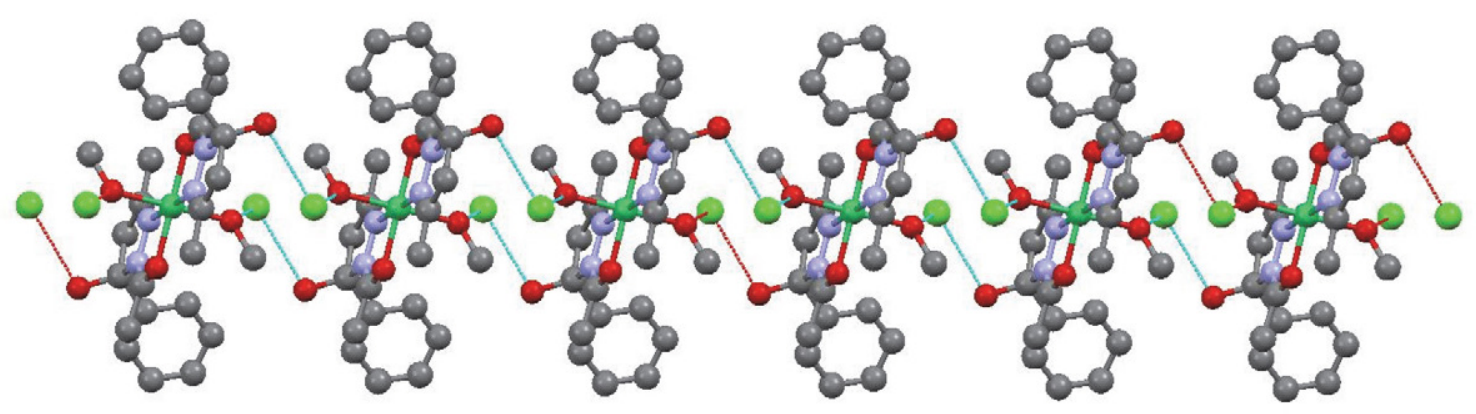

Fig. 2. The hydrogen bonding interactions between uncoordinated hydroxyl group of ligand and the chloride counter anions in complex $\mathbf{1}$ along $b$ axis.

Table 3. Hydrogen bonding $(\AA)$ and angles $\left(^{\circ}\right)$ in complex 1

\begin{tabular}{cccccc}
\hline D-H $\cdots \boldsymbol{A}$ & $\mathbf{D}-\mathbf{H}$ & $\mathbf{H} \cdots \boldsymbol{A}$ & $\mathbf{D} \ldots \boldsymbol{A}$ & $\mathbf{D}-\mathbf{H} \cdots \boldsymbol{A}$ & Symmetry code \\
\hline $\mathrm{O} 2-\mathrm{H} 2 \cdots \mathrm{Cl} 1$ & $0.77(2)$ & $2.33(2)$ & $3.093(1)$ & $174.9(19)$ & $-x,-y+1,-z+1$ \\
$\mathrm{O} 3-\mathrm{H} 3 \cdots \mathrm{Cl} 1$ & $0.83(2)$ & $2.16(2)$ & $2.987(1)$ & $173.0(20)$ & \\
\hline
\end{tabular}



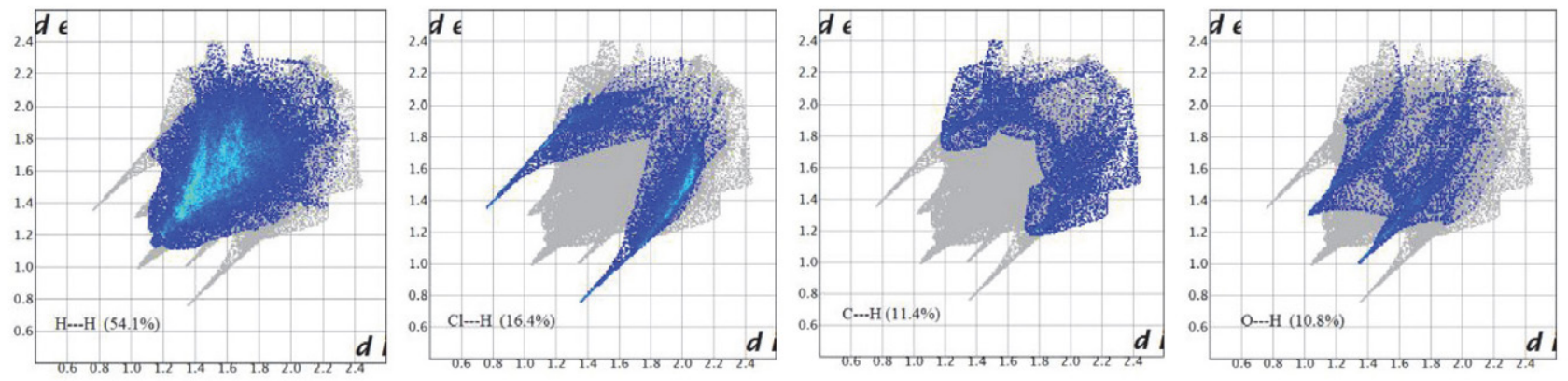

Fig. 4. The $2 \mathrm{D}$ fingerprint plots and relative contributions to the percentage of Hirshfeld surface for various interactions in complex $\mathbf{1}$.

positive or negative when intermolecular contacts are longer or shorter than the sum van der Waals radii of the atoms (vdW), respectively. The $d_{\text {norm }}$ values are mapped onto the Hirshfeld surface using a red-blue-white color scheme. Red regions correspond to closer contacts and negative $d_{\text {norm }}$ value, the blue regions correspond to longer contacts and positive $d_{\text {norm }}$ value. The white-colored regions correspond to weak contacts and the distance of contacts is around the vdW separation $\left(d_{\text {norm }} \approx 0\right) .{ }^{33-35}$

The 2D fingerprint plot and the contribution of each type of interaction are describe in Fig. 4 . The $\mathrm{H} \cdots \mathrm{H}$ interaction (54.1\%) appears as wide and blunt spikes in the region $1.15 \AA<(d \mathrm{e}+d \mathrm{i})<1.70 \AA$. The $\mathrm{Cl} \cdots \mathrm{H} / \mathrm{H} \cdots \mathrm{Cl}$ interaction $(16.4 \%)$ also appears as two distinct spikes, the lower spike corresponding to the acceptor spike represents the $\mathrm{Cl} \cdots \mathrm{H}$ interactions $(d \mathrm{i}=1.35 \AA$ and $d \mathrm{e}=0.75 \AA$ ) and the upper spike being a donor spike represents the $\mathrm{H}$... O interactions $(d \mathrm{e}=1.35 \AA$ and $d \mathrm{i}=0.9 \AA)$ in the fingerprint plots. Further, the $\mathrm{C} \cdots \mathrm{H} / \mathrm{H} \cdots \mathrm{C}$ interaction which comprise $10.2 \%$ of the total Hirshfeld surfaces were appeared as two distinct spikes, the C...H interaction with de $=1.17 \AA$ and $\mathrm{di}$ $=1.70 \AA$ and $\mathrm{H} \cdots \mathrm{C}$ interaction with de $=1.70 \AA$ and $\mathrm{di}=$ $1.17 \AA$. The $\mathrm{O} \cdots \mathrm{H} / \mathrm{H} \cdots \mathrm{O}$ interactions comprise $10.8 \%$ of the total Hirshfeld surfaces with de $=1.17 \AA$ and $\mathrm{di}=1.70$ $\AA$ and $\mathrm{de}=1.70 \AA$ and $\mathrm{di}=1.17 \AA$ for $\mathrm{O} \cdots \mathrm{H}$ and $\mathrm{H} \cdots \mathrm{O}$ interactions, respectively.

\section{Conclusion}

The $\left.\mathrm{Ni}\left(\mathrm{L}^{\mathrm{p}}\right)_{2}\left(\mathrm{CH}_{3} \mathrm{OH}\right)_{2}\right] \mathrm{Cl}_{2}$ complex was obtained as an unexpected product from reaction of $\mathrm{NiCl}_{2}$ with $\mathrm{HL}$ at room temperature. In the $\mathrm{Ni}$ (II) complex, metal center is hexacoordinated with a distorted octahedral geometry. The ligand coordinates to the metal center as a neutral bidentate ligand, while in the reaction of copper(II) salts with this ligand, as previously reported, the ligand acts as a monoanionic tridentate ligand. In the reaction with $\mathrm{NiCl}_{2}$, the ligand was converted in situ into the pyrazole ligand, $\mathrm{L}^{\mathrm{P}}$ in a cyclization reaction. The Hirshfeld surface analyses and the fingerprint plots provide some useful quantitative information about the role of intermolecular contacts in the crystal packing.

\section{Supplementary material}

The deposition numbers of the studied complex is CCDC 1949210. This data can be obtained free-of-charge via www.ccdc.cam.ac.uk/data_request/cif, by emailing data-request@ccdc.cam.ac.uk, or by contacting The Cambridge Crystallographic Data Centre, 12 Union Road, Cambridge CB2 1EZ, UK; fax +44 1223336033.

\section{Acknowledgments}

The authors are grateful to the Yazd University and the Australian National University for partial support of this work.

\section{References}

1. R. Vafazadeh, M. Ehsani1, A. C. Willis, J. Iran. Chem. Soc. 2019, 16, 2509-2518. DOI:10.1007/s13738-019-01721-3

2. T. Ghosh, S. Pal, Inorg. Chim. Acta 2010, 363, 3632-3636. DOI:10.1016/j.ica.2010.07.007

3. R. Vafazadeh, R. Esteghamat-Panah, A. C. Willis, A. F. Hill, Polyhedron, 2012, 48, 51-57. DOI:10.1016/j.poly.2012.08.057

4. R. Vafazadeh, Z. Moghadas, A.C. Willis, J. Coord. Chem., 2015, 68, 4255-5271. DOI:10.1080/00958972.2015.1096349

5. R. Vafazadeh, N. Abdollahi, A.C. Willis, Acta Chim. Slov. 2017, 64, 409-414. DOI:10.17344/acsi.2017.3263

6. A. Mukhopadhyay, S. Pal, Polyhedron 2004, 23, 1997-2004. DOI:10.1016/j.poly.2004.05.002

7. A. Mukhopadhyay, S. Pal, Eur. J. Inorg. Chem. 2009, 41414148. DOI:10.1002/ejic.200900472

8. R. Vafazadeh, N. Hasanzade, M. M. Heidari, A. C. Willis, Acta Chim. Slov. 2015, 62, 122-129. DOI:10.17344/acsi.2014.797

9. R. Vafazadeh, A. C. Willis, Acta Chim. Slov. 2016, 63, 186-192.

10. K. Sancak, M. Er, Y. Unver, M. Yildirim, I. Degirmencioglu, Transit. Met. Chem. 2007, 32, 16-22.

11. P. P. Devi, F. A.S. Chipem, C. B. Singh, R. K. Lonibala, J. Mol. Struct. 2019, 1176, 7-18.

DOI:10.1016/j.molstruc.2018.08.070

12. G. He, X. Hua, N. Yang, L. Li, J. Xu, L. Yang, Q. Wang, L. Ji, Bioorg. Chem. 2019, 91, 103176-103178.

DOI:10.1016/j.bioorg.2019.103176 
13. G. A. Gamov, M. N. Zavalishin, A. Y. Khokhlova, A. V. Gashnikova, V. V. Aleksandriiskii, V. A. Sharnin, J. Coord. Chem. 2018, 71, 3304-3314. DOI:10.1080/00958972.2018.1512708

14. P. Tyagi, M. Tyagi, S. Agrawal, S. Chandra, H. Ojha, M. Pathak, Spectrochim. Acta A. 2017, 171, 246-257.

DOI:10.1016/j.saa.2016.08.008

15. R. Vafazadeh, M. Alinaghi, A. C. Willis, A. Benvidi, Acta Chim. Slov., 2014, 61, 121-125.

16. Z.-X. Wang, H.-L. Qin, Green Chem. 2004, 6, 90-92. DOI:10.1039/b312833d

17. A. Alberola, L. Calvo, A. G. Ortega, M. L. Sidaba, M. C. Saiiudo, S. G. Granda, E. G. Rodriguezt, Heterocycles 1999, 51, 2675-2686. DOI:10.3987/COM-99-8683

18. Z. Otwinowski, W. Minor. Methods in Enzymology, edited by C. W. Carter Jr \& R. M.W. Sweet, New York: Academic Press, 1997, 276, pp. 307-326. DOI:10.1016/S0076-6879(97)76066-X

19. A. Altomare, G. Cascarano, G. Giacovazzo, A. Guagliardi, M. C. Burla, G. Polidori, M. Camalli, J. Appl. Cryst. 1994, 27, 435-436. DOI:10.1107/S0021889894000221

20. P. W. Betteridge, J. R. Carruthers, R. I. Cooper, K. Prout, D. J. Watkin, J. Appl. Cryst. 2003, 36, 1487-1487.

DOI:10.1107/S0021889803021800

21. K. Wolff, D. J. Grimwood, J. J. McKinnon, M. J. Turner, D. Jayatilaka, M. A. Spackman. CrystalExplorer, Version 3.0. University of Western Australia, 2012.

22. K. Nakamoto, Infrared and Raman Spectra of Inorganic and Coordination Compounds, fourth ed., Wiley, New York, 1986.
23. R. Vafazadeh, F. Jafari, M. M. Heidari, A.C. Willis, J. Coord. Chem. 2016, 69, 1313-1325.

DOI:10.1080/00958972.2016.1163547

24. M. Shebl, S. M. E. Khalil, Monatsh Chem. 2015, 146, 15-33. DOI:10.1007/s00706-014-1302-x

25. R. Vafazadeh, B. Khaledi, A. C Willis, Acta Chim. Slov. 2012,59, 954-958.

26. R. Vafazadeh, A. Kazemi-nasab, A. C. Willis, Acta Chim. Slov. 2019, 66, 1010-1018. DOI:10.17344/acsi.2019.5333

27. M. Barwiolek, E. Szlyk, A. Berg, A. Wojtczak, T. Muziol, J. Jezierska, Dalton Trans., 2014, 43, 9924-9933. DOI:10.1039/ C4DT00654B

28. M. Dolai, T. Mistri, A. Panja, M. Ali, Inorg. Chim. Acta 2013, 399, 95-104. DOI:10.1016/j.ica.2013.01.006

29. R. Vafazadeh, M. Namazian, B. Shahpoori-Arani, A. C. Willis, P. D. Carr, Acta Chim. Slov. 2018, 65, 372-379. DOI:10.17344/acsi.2017.4096

30. L. Radovanović, J. Rogan, D. Poleti, M. V. Rodić, Z. Jagličić, Acta Chim. Slov. 2018, 65, 191-198. DOI:10.17344/acsi.2017.3813

31. R. Vafazadeh, A. Gorji, S. Ansari, A. C. Willis, Acta Chim. Slov. 2012, 59, 897-903.

32. P. M. V. Kumar, P. K. Radhakrishnan, Inorg. Chim. Acta 2011 , 375, 84-92. DOI:10.1016/j.ica.2011.04.034

33. M. A. Spackman, D. Jayatilaka, CrystEngComm 2009, 11, 19-32. DOI:10.1039/B818330A

34. Y. X. Sun, L. Z. Liu, F. Wang, X. Y. Shang, L. Chen, W. K. Dong, Crystals 2018, 8, 227-239.

DOI: $10.3390 /$ cryst 8050227

35. N. Khelloul, K. Toubal, N. Benhalima, R. Rahmani, A. Chouaih, A. Djafri, F. Hamzaoui, Acta Chim. Slov. 2016, 63, 619-626. DOI:10.17344/acsi.2016.2362

\section{Povzetek}

Sintetizirali smo enojedrni $\mathrm{Ni}(\mathrm{II})$ kompleks $\left[\mathrm{Ni}\left(\mathrm{L}^{\mathrm{P}}\right)_{2}\left(\mathrm{CH}_{3} \mathrm{OH}\right)_{2}\right] \mathrm{Cl}_{2}$ z reakcijo 1-(5-hidroksi-3-metil-5-fenil-4,5-dihidro$1 \mathrm{H}$-pirazol-1-il)etan-1-ona (HL) $\mathrm{z} \mathrm{NiCl} \cdot 6 \mathrm{H}_{2} \mathrm{O}$ v metanolu. Tekom reakcije se je trovezni ligand $\mathrm{HL}$ in situ pretvoril $\mathrm{v}$ 4-hidroksi-4-fenilbut-3-en-2-iliden)acetohidrazidni ligand, (pirazol, L ${ }^{p}$ ). Pirazolni ligand je dvovezni nevtralni ligand katerega hidroksilna skupina se ne koordinira. Struktura Ni(II) kompleksa je bila določena z rentgensko kristalografijo. $\mathrm{Ni}(\mathrm{II})$ ima popačeno oktaedrično geometrijo. Nanj sta vezana dva dušikova atoma in dva kisikova atoma $\mathrm{z}$ dveh pirazolskih ligandov ter dve molekuli metanola. Intermolekularni kontakti v kristalni strukturi so bili študirani z Hirshfeldovo analizo površine in $2 \mathrm{D}$ diagrami prstnih odtisov. Glavni intermolekularni kontakti so $\mathrm{H} / \mathrm{H}$ in $\mathrm{Cl} / \mathrm{H}$ interakcije.

Except when otherwise noted, articles in this journal are published under the terms and conditions of the Creative Commons Attribution 4.0 International License 